https://doi.org/10.31470/2706-7904-2021-16-279-282

\title{
НОМІНАЦІЯ ВІРТУАЛЬНОЇ ОСОБИСТОСТІ КОРИСТУВАЧІВ СОЦАЛЬНИХ МЕРЕЖ
}

Nomination of the Virtual Identity of Social Network Users

\author{
Kseniia Taranenko \\ Ph.D. in Philology, Associate Professor \\ National Technical University "Dnipro Polytechnic" (Ukraine) \\ xtaranenko@gmail.com \\ https://orcid.org/0000-0001-6518-0426 \\ Vladyslava Lobanova \\ Student \\ National Technical University "Dnipro Polytechnic" (Ukraine) \\ Lobanova.V.O@nmu.one
}

\begin{abstract}
The article considers the concept of virtual personality, its structure. An analysis of ways to nominate users of social networks Instagram and Telegram. The pragmatic features of virtual personality onyms have been studied.
\end{abstract}

Key words: onyms, virtual personality, social networks, allusion.

\section{Вступ \\ Introduction}

На сучасному етапі розвитку суспільства актуальним завданням ономастики $є$ дослідження прагматики номінації користувачів соціальних мереж. Уявити сучасну людину без соціальних мереж чи месенджерів доволі складно. Однак на відміну від реального спілкування у віртуальному світі соціальних мереж ми самостійно вибудовуємо стратегію презентації свого Я за допомогою світлин, назви профілю та інформації про себе. Кожен користувач соціальних мереж створює віртуальну особистість - "Віртуальне-Я”. Н.Н. Корольова (2014) зазначає, що “віртуальна особистість", "мережева або віртуальна ідентичність", “Я-віртуальне" і т.п. похідні від поняття "Віртуальне-Я”, з одного боку, будуються на підставі смислових складників “Реального-Я”, 3 іншого - «Ідеального-Я» (там само). Віртуальна 
особистість постає окремим специфічним соціальним феноменом, адже може за усіма своїми базовими показниками значною мірою відрізнятись від реальної особистості в ii стандартизованій, типовій соціальній ролі. На думку Т.Б. Карпової (2007), віртуальна особистість проявляє себе саме в мовній сфері. Віртуальна мовна особистість існує як узагальнений образ носія мовних знань, культурних цінностей, індивідуального мовного стилю комунікативно-діяльнісних установок. Одним із найважливіших чинників образу “Я-віртуального” є номінація користувача у певній соціальній мережі. У межах віртуальної комунікації такий онім є явищем штучної номінації, оскільки користувач самостійно й свідомо творить онім для себе, що за рядом ознак наближає його до прізвиська чи псевдоніму, а за окремими параметрами до оказіоналізму чи неологізму. Основними специфічними ознаками оніма в соціальних мережах $\epsilon$ : визначеність номінації, наявність одиничної референції, яскрава вираженість конотативного i прагматичного компонентів лексичного значення, що зумовлено комунікативною спрямованістю. Віртуальне спілкування дозволяє людині оминути обмеження реального життя та реалізувати свій мовотворчій потенціал, надає можливості втілити у мовній поведінці найрізноманітніші засоби сапопрезентації, творчо підійти до створення власного мовного образу.

Метою пропонованої розвідки $є$ аналіз способів номінації користувачів соціальних мереж та вивчення особливостей онімів віртуальної особистості.

\section{Методи та методики дослідження Methods and Techniques of the Research}

Матеріал дослідження дібрано шляхом суцільної вибірки онімів користувачів Instagram та Telegram. Укладено картотеку онімів зі 256 одиниць. Базовим методом дослідження став метод дискурсивного аналізу для комплексного опису ситуацій вияву пасивної агресії з урахуванням функціональних, психологічних, соціальних складників та виділення тактик мовленнєвої поведінки пасивних агресорів. Методологія дослідження об’єднала як загальнонаукові методи (спостереження, статистичний, синтез, аналіз, узагальнення), так i лінгвістичні. Основним лінгвістичним методом став ономастичний - спосіб пізнання й дослідження в галузі ономастики. Для дослідження морфемної й словотворчої структури онімів застосовано структурний та формантний методи, а також етимологічний, який дав змогу встановити походження оніма чи групи онімів, пов'язаних між собою. 


\section{Результати \\ Results}

Привласнюючи собі ім'я користувач соціальних мереж керується рядом мотивів, якими може бути пояснений вибір мовних засобів. На думку Л. Михайлової, мотивами створення віртуальної особистості є:

(1) конструювання “Ідеального-я” у віртуальній реальності дозволяє особистості з одного боку компенсувати те, що неможливо досягти, 3 іншого боку - надає можливість переносу віртуального в реальне;

(2) прагнення реалізувати притаманні особистості агресивні негативні тенденції, які засуджуються суспільством і які неможливо реалізувати в реальному соціальному середовищі;

(3) бажання контролювати себе, свої деструктивні тенденції. У результаті відбувається деякий процес навчання, що надає можливість особистості контролювати їх у реальній дійсності;

(4) бажання справити враження на інших відповідно до наявних норм або усупереч ними, що залежить від ступеню нормативності чи модальності особистості;

(5) прагнення до влади, що засноване на відповідних якостях та властивостях, але таке, що не реалізується у соціальній дійсності;

(6) віртуальна зміна статі;

(7) прагнення випробувати раніш невипробуване (Михайлова, 2011).

Ігровий характер віртуальної комунікації має безпосередній вплив на особливості функціонування онімів у соціальних мережах. Презентуючи себе віртуальному співтовариству, користувач керується стратегією «Я - особистість віртуальна».

В ономастичній системі віртуального спілкування можна виділити оніми, які можуть бути ототожнені з прізвиськами. В ономастиці прізвиська визначаються як неофіційні експресивно-образні чи емоційно-оцінні імена, що використовуються додатково до антропоніма чи замість нього. Віртуальні «прізвиська» відрізняються від прізвиськ у реальному житті тим, що людина самостійно вигадує його собі або ж свідомо погоджується на те, що існує у реальному спілкуванні. Функціональна особливість онімів, що полягає в самоназиванні, дозволяє відмежовувати їх від власне прізвиськ, хоча i ті, й ті індивідуалізують особу за певною ознакою і мають невичерпний матеріал для їх утворення. Такі віртуальні прізвиська можуть характеризувати професійну діяльність користувача соціальних мереж (vilnyj_hudozhnyk, freelancer, artist, sisadmin тощо), фах, здібності чи захоплення (dancer, вічний студент, i_love_music, i_love_foto, in_love.fashion тощо), риси 
характеру чи зовнішності (мілаЯ, so_switty, nice_girl, чорнобровий, beautifulgirl тощо), конкретну життєву ситуацію (eto ne to chto ty podumala, poмa вдома, Это_Hе_Я тощо). Віртуальний онім, на відміну від прізвиська, може виражати бажані й удавані риси (тот самый прБнц, irkosuperstar, почти багатая и знаменитая, королева_ночі), а не лише реальні. Користувач у такий спосіб створює образ, “Віртуальне-Я”, принижує, вихваляє чи рекламує себе.

Віртуальні оніми як одиниці вторинної номінації можуть бути похідними від справжніх імен чи прізвищ, в яких більшою мірою виражений конотативний та прагматичниq компоненти значень, наприклад: vikusya, mamamarina, lesusha, жекан, da_dusya.

Окрему групу віртуальних онімів користувачів соціальних мереж становлять імена-алюзії, побудовані на використанні широко вживаного вислову, що натякає на який-небудь загальновідомий історичний, міфологічний, літературний або побутовий факт. Серед онімів-алюзій можна виокремити такі: whatislove, всім реace, dance_with_me, happy_life, отчаянная домохозяйка, Алиса в стране чудес, agent007.

\section{Висновки \\ Conclusions}

Отже, мовна особистість отримує безмежні можливості реалізації “Явіртуального" у соціальних мережах. Віртуальні оніми - це нова форма самопрезентації особистості. Віртуальні оніми не можуть бути повністю ототожнені iз псевдонімами, прізвиськами чи оказіоналізмами, оскільки мають специфічні особливості когнітивного, психологічного, соціального, прагматичного і вербальносемантичного вияву у віртуальному спілкуванні.

\section{Література \\ References}

Карпова Т.Б. (2007). Самовыражение личности в Интернете: лингвистический аспект. Русский язык: исторические судьбы и современность: Сб. науч. ст. по материалам докл. и сообщ. междунар. конгресса (с. 384-385). Москва: МАКС Пресс.

Королева, Н., Богдановская, И.М., \& Луговая, В.Ф. (2014). Воздействие современной информационной и медиа среды на образ «Я» подростков. Universum: Becтник Гериеновского университета, 2, 87-94.

Михайлова, Л. (2011). Человек в виртуальной реальности - новый образ жизни. URL: www.rusnauka.com/28_PRNT_2011/Psihologia/12_93665.doc.htm 